\title{
Iron as Preoperative Antituberculosis Supplement Increases Interleukin-12 Level in Spinal Tuberculosis and Iron Deficiency Patients
}

\author{
Anggi Fauziani, Nucki Nursjamsi Hidajat, Ahmad Ramdan, Agus Hadian Rahim \\ Department of Orthopaedic and Traumatology \\ Faculty of Medicine Universitas Padjadjaran/Dr. Hasan Sadikin Hospital Bandung
}

\begin{abstract}
Iron deficiency remains the most prevalent micronutrient deficiency worldwide. Iron deficiency in TB patients, causes a poor outcome, reccurency, and treatment failure. Iron supplements on TB patients with iron deficiency will activate macrophage-derived monocytes (MDM) and interferon-gamma (IFN- $\gamma$ ), with a positive feedback mechanism pushing interleukin-12 (IL-12). This study is a single-blind randomized control trial comparing the effectivity of preoperative iron supplementation in IL-12 level between two different groups in Dr. Hasan Sadikin General Hospital Bandung, conducted from November 2018 until March 2019. Respondents are those having Spondylitis TB, with sTfR $>21,7 \mathrm{pg} / \mathrm{mL}$ and IL- $12<41 \mathrm{pg} / \mathrm{mL}$, intensive phase antituberculosis drugs category 1 . The experimental group, comprised 17 respondents, was treated with 2RHZE and $357 \mathrm{mg}$ iron (III) hidroxy polymaltosa. The control group was treated with 2RHZE. The sTfR and IL-12 levels were performed before and after treatment. The increase of IL- 12 in the experimental group was $+364,53 \%$ higher than in the control group $(\mathrm{p}<0.05)$. The decrease of $\mathrm{sTfR}$ in the experimental group was $-60,68 \%$ higher than in the control group $(p<0.05)$. The result of the Pearson correlation test was a coefficient correlation of $-0,73$, this showed that a decrease in the sTfR level correlated with an increase in the Il-12 level. Iron supplement in Spondylitis TB with iron deficiency in the experimental group increases the IL-12 level. Preoperative iron supplementation on spondylitis TB with iron deficiency, increases the immune system with higher levels of IL-12.
\end{abstract}

Key words: Interleukin-12, iron supplementation, spinal tuberculosis

\section{Perbedaan Kadar IL-12 pada Terapi Pre-Operatif Spondilitis TB dengan Defisiensi Zat Besi yang diberikan Suplementasi Zat Besi}

\begin{abstract}
Abstrak
Defisiensi Fe merupakan defisiensi mikronutrien paling sering di seluruh dunia, jika terjadi pada penderita TB akan meningkatkan risiko prognosa buruk, rekurensi, MDR, dan gagal terapi. Suplementasi besi pada tuberkulosa dengan defisiensi besi akan meningkatkan sistem imun dengan mengaktivasi macrophage derived monocyt, dan interferon-gamma, dengan mekanisme umpan balik positif memacu interleukin- 12 . Single blind randomized control trial untuk membandingkan efektivitas Fe terhadap kenaikan IL-12 pada terapi preoperatif spondilitis TB di RSHS periode Nopember 2018-Maret 2019. Metode sampling; consecutive sampling. Subjek sebanyak 34 orang; Penderita spondilitis TB, sTfR $>21,7 \mathrm{pg} / \mathrm{ml} \mathrm{dan} \mathrm{IL-12<41} \mathrm{pg/mL.} \mathrm{fase}$ intensif OAT kategori 1sesuai dengan standar WHO. Kelompok eksperimen, 17responden diterapi 2 RHZE + tablet iron (III) hidroksi polimaltosa357 mg selama 2 bulan. Kelompok kontrol 17 responden diterapi 2RHZE. Peningkatan IL-12 pada kelompok eksperimen sebesar $+364,53 \%$ lebih besar dari kelompok kontrol $(p<0,05)$ dan; Penurunan kadar sTfR pada kelompok eksperimen sebesar $-60,68 \%(p<0,05)$ lebih besar dari kontrol. Uji korelasi sTfR dan IL-12 dengan Pearson ; korelasi -0,763, menunjukkan korelasi kuat antara penurunan sTfR dan kenaikan nilai IL-12. Suplementasi Fe pada terapi preoperatif spondilitis TB dengan defisiensi Fe meningkatkan respon imun yang ditandai dengan meningkatnya IL-12.
\end{abstract}

Kata kunci: Interleukin-12, spondilitis TB, zat besi

Corespondence: dr. Anggi Fauziani, Department of Orthopaedic and Traumatology Faculty of Medicine Universitas Padjadjaran/Dr. Hasan Sadikin Hospital Bandung, Jl. Pasteur No. 38 Bandung 40161, Email giefauzia@gmail.com 


\section{Introduction}

Tuberkulosis (TB) is one of the significant public health threats, competing with human immunodeficiency virus (HIV) as the cause of death due to infectious disease. In 2017, $87 \%$ of new TB cases occurred in the 30 high TB burden countries.1 Indonesia was in 3rd position after India and China, with an incidence rate of 395 per 100.000 citizans and mortality rate 27,3 per 100.000 per citizen. 1 Over $95 \%$ of cases and deaths are in developing countries, including Indonesia. ${ }^{1}$ Major achievements have been made in reducing the global burden of TB with the expansion of efforts to improve TB care and control, but TB remains an important global health concern. ${ }^{2}$

Tuberculosis caused by bacteria mycobacterium tuberculosis most often affect the lungs.1,3 TB affects adults in their most productive years; however, all age groups are at risk. $^{1}$ Nearly $20 \%$ of patients with TB develop extrapulmonary manifestations. ${ }^{1}$ Skeletal TB accounts for $10-20 \%$ of all extrapulmonary $\mathrm{TB}$, with spinal involvement in $50-60 \%$ of all skeletal TB cases. This has been a tough challenge to all community to control this infection. ${ }^{3,4}$

Spinal TB is the most common and worst form of TB lesion; spinal TB can cause bone destruction, kyphosis deformity, and paraplegia. ${ }^{4,5}$ Motor and sensory neurological impairment were found in $77.1 \%$ of spinal TB cases. ${ }^{4}$ Because of the high morbidity rate with this disease, the authors are interested in research on the prevention, medication, and rehabilitation to reduce the rate of the morbidity and death due to TB. ${ }^{5}$

Iron deficiency in tuberculosis have been reported since 1986, one study conducted by Baynes et al., states that iron deficiency reduce celuller immunity, even without anemia. Iron deficiency in TB patient is caused by several mechanism, such as malabsorption, reduction iron uptake in duodenum caused a reduction in the body's ability to utilize sufficient iron for effective erythropoiesis by hepcidin expression in TB patients, iron acquisition from macrophage led to iron recycle restricted. $2,6,7$
MTB extract iron from the extracelluler matrix that causes iron level decreasing.4Chronic or severe iron deficiency led to iron deficiency Anemia (IDA). Many studies had documented a high prevalence of anemia in TB patients (30-94\%), and evidence suggests that anemia in TB increases the risk of death. Any effort to alleviate Iron deficiency will improve treatment outcome of TB patients. ${ }^{2}$ Iron is necessary for survival of all cells in culture. Iron is required for the activity of ribonucleotide reductase the enzyme responsible for synthesis of deoxyribonucleotides, and therefore is needed for DNA synthesis. ${ }^{8,9}$

Iron deficiency is associated with reversible abnormalities of immune function. Both experimental, and some clinical studies have emphasized the importance of iron in the integrity of the immune system especially the innate immunity (decreased bactericidal effect and respiratory burst of neutrophils) and the cellular component system of cell-mediated immunity (CMI) (decreased lymphocyte proliferation and delayed hypersensitivity responses). ${ }^{2}$

A study was conducted by Subagyo et al. of iron as suplementation in pulmonary tuberculosis patients with iron deficiency anemia towards healing response, immune response and resistency. ${ }^{10}$ The study results show that iron supplementation enhances healing response measured by the conversion of BTA sputum. The immune response measured by increasing level of IFN- $\gamma$, IL12, hemoglobin, IMT, and MDR resistence measured by double alkali mutation.4 As stated in a study by Tatar et al., the immune system in extrapulmonary TB patient is much lower than pulmonary TB patient.11 There is no research on iron supplementation in extrapulmonay $\mathrm{TB}$, especially spondylitis TB, as among the severe ones.

Efforts to identify and address the conditions contributing to TB-associated anemia, including iron deficiency, could play an essential role in reducing morbidity and mortality in areas profoundly affected. Our research aimed to determine whether oral iron supplementation as a supplement can 
increase the effectivity of anti-tuberculous drugs (ATDs) through evaluating the immune marker cytokine inteleukin-12 (IL-12) in spondylitis TB patient with iron deficiency.

This study used soluble transferrin receptor (sTfR) to asess the iron level. StfR is a transferrin protein derived from erythroid cells. StfR will increase in response to low supply of iron to the tissue; it is a sensitive response to early iron deficiency. The advantages of sTfr tests are unaffected by infection or inflammation process, age, gender nor pregnancy.

\section{Methods}

This study used a single-blind randomized controlled trial design. All spinal TB patients at the Hasan Sadikin Hospital, who were medicated with ATD and met the inclusion and exclusion criteria, were randomLy divided into two groups. Group 1 was the intervention group, which was given 357 mg iron polymaltose (III) tablet, and Group 2 was the control group. Both groups were followed for two months and their sTfR and IL-12 level measured at recruitment and two months after ATD medication. Laboratory examinations were performed in the Dr. Hasan Sadikin General Hospital laboratory. The sTfR and IL-12 serum concentration examinations used a colorimetric reader using ELISA tests. The research subjects were all spinal TB outpatients or inpatients at Dr. Hasan Sadikin General Hospital Bandung. The inclusion criteria were age: $18-55$ years; $\mathrm{sTfR}>21,7 \mathrm{pg} /$ mL.; IL-12 < 41 pg/mL. Exclusion criteria were a history of TB, diabetes mellitus, hypertension, autoimmune disease, or thyroid disease; a long-term steroid medication; lung or kidney function disorder; pregnant or breastfeeding woman; Regulary took medication Allopurinol, Antacid, H2 receptor block (ranitidine), proton pump inhibitor. Repetitive transfusion, iron disorder, and allergic to iron. Research subjects were dropped from the study if they received surgery within the research period.

This study used a consecutive sampling method with 17 people in each group. The intervention group received iron polymaltose (III) tablet+ ATD. The control group only received ATD. For the relationship between sTfR and changes in IL-12 concentration, we used the independent t-test. To analyze the correlation between STfR and IL-12 we used the Spearman and the Pearson correlation tests.

This study has been approved by the Ethical Committee of Dr. Hasan Sadikin General Hospital Bandung, with the ethical approval number LB.04.01/A05/EC/315/XI/2018.

\section{Results}

Characteristics of each group (sex, age, BMI, location of lesion, severity of lesion by Frankle classification and Haemoglobin) showed that the average age in the intervention group was 31.8 years [standard deviation (SD) \pm 11.65 ] and in the control group was 40,29 years

Table 1 Table characteristics

\begin{tabular}{lcc} 
Characteristics & $\begin{array}{c}\text { ATD + 357 mg } \\
\text { iron polymaltose (III) } \\
\text { (n=17) }\end{array}$ & $\begin{array}{c}\text { ATD } \\
\text { (n=17) }\end{array}$ \\
\hline Sex $\quad$ Male & 9 & 8 \\
$\quad$ Female & 8 & 9 \\
Age (years), average (SD) & $31,88,(11,65)$ & $40,29,(12,89)$ \\
Body mass index (BMI) (kg/m2), average (SD) & $20,0,(2,64)$ & $19,4,(2,38)$ \\
Spine level (frequency) & & 10 \\
Thoracal & 9 & 7 \\
Lumbal & 8 & $10,55 .(1,68)$ \\
Haemoglobin pre-treatmet, mean & $10,09 .(2,59)$ & \\
\hline
\end{tabular}


Table 2 Correlation IL-12 and sTfR concentration in the intervention group before and after Fe supplementation

\begin{tabular}{lccc}
\hline & $\begin{array}{c}\text { ATD + 357 mg iron } \\
\text { polymaltose (III) }\end{array}$ & ATD & p value \\
\hline IL-12 (pg/mL) avarage) & & & \\
Before (min; max) & $14,16(3,98 ; 30,45)$ & $13,99(2,48 ; 28,04)$ & $\# 0,943$ \\
After (min; max) & $63,23(38,22 ; 105,36)$ & $30,24(16,42 ; 53,13)$ & $\# 0,000$ \\
Difference (min; max) & $49,07(34,24 ; 74,91)$ & $16,25(13,94 ; 25,09)$ & $\# 0,000$ \\
sTfR (pg/mL) Avarage (min; max) & & & \\
Before (min; max) & $56,12(50,13 ; 79,19)$ & $57,87(50,87 ; 76,31)$ & $\# 0,982$ \\
After (min; max) & $20,51(26,95 ; 12,41)$ & $36,26(40,15 ; 26,62)$ & $\# 0.000$ \\
Difference (min; max) & $35,61(23,18 ; 66,78)$ & $21,61(10,72 ; 49,62)$ & $\# 0,000$ \\
\hline
\end{tabular}

(SD $\pm 12,89$ ). The average BMI was $20.0 \mathrm{~kg} /$ $\mathrm{m} 2(\mathrm{SD} \pm 2,64)$ in intervension group and 19.4 $(\mathrm{SD} \pm 2.38)$ in the control group. The differences in characteristics between the groups were not statistically significant (Table 1 ).

Furthermore, the different level of sTfR and IL-12 before treatment was not signifficant. The sTfR concentration in the intervention group before supplementation was $56,12 \mathrm{pg} / \mathrm{mL}$, and after supplementation, it was $35.61 \mathrm{pg} /$ $\mathrm{mL}$. Differences were analyzed with the paired t-test and found to be statistically significant $(p<0.001)$. It was significant that the decrease of the sTfR level was after treatment compared with before treatment (Table 2).

Similarly, there was a statistically significant increase in IL-12 concentrations after supplementation with $357 \mathrm{mg}$ iron polymaltose (III) for two months $(\mathrm{p}<0.001$ and $\mathrm{p}<0.03$, respectively) (Table 2 ).

Correlation between stFr and IL-12 concentration before and after vitamin $\mathrm{Fe}$ supplementation used the Pearson test. There was a significant correlation between the decreasing level of sTfR and increasing level of IL-12, with a coefficient $-0,763$.

\section{Discussion}

After randomization, the potentially confounding variables were found distributed evenly between the intervention group and the control group (Table 1). In this study, Gibbus deformity was typically located in the thoracic vertebrae. It is caused by the Adamkiewicz artery, a segmental blood vessel located in the thoracolumbar vertebral region. This artery supplies the body of the vertebrae and might carry MTB bacteria to the vertebrae. ${ }^{5}$

Spondylitis TB is a serious problem for publichealth 12 that often occurs in high burden TB incidence such as Indonesia. According to The British Medical Research Council Working Party on Spinal Tuberculosis, ${ }^{12,13}$ antituberculosis drug (ATD) is the primary treatment for spondylitis TB without complications. ATD has improved the results of conservative and radical restorative operative treatments. ${ }^{5,13}$ TB is a catabolic disease that consumes much energy, with symptoms such as decreasing body weight, anemia, malnutrition, and hypoproteinemia, making it difficult to provide a suitable environment for healing. Furthermore, Cao et al report nutritional status as one of the responsible factors for worse prognosis. ${ }^{17}$ Besides, Wang et al report a low level of haemoglobin as predisposition factor for reccurence and postoperative sinus tract complications in spondylitis TB treatment; Wang reccomended preoperative fresh erytrocyte suspension and albumin transfusion. ${ }^{15}$ Moreover, Froissat et al. report that red blood cell transfusion will not influence the sTfR level, which means fungsional iron level is unaffected by transfusion. Iron deficiency cannot be 
corrected by blood transfusion. ${ }^{16}$

A study by Subagyo et al. ${ }^{10}$ reports that iron as supplementation in pulmonary tuberculosis patients with iron deficiency anemia enhances Immune response, which is measured by increasing level IFN- $\gamma$ and IL12.We studied the effect of preoperative iron supplementation in iron deficiency spondylitis TB patients with IL-12 parameter.

Haemoglobin level for both groups had an almost similiar average level, which was $10,09 \mathrm{gr} / \mathrm{dL}$ on the intervention group, and $10.55 \mathrm{gr} / \mathrm{dL}$ on the control group. It observed that the $\mathrm{Hb}$ level did not decrease below $10 \mathrm{gr} / \mathrm{dl}$. However, both groups were categorized as iron deficiency. The mean for sTfR concentration in the control group was $57,92 \mathrm{pg} / \mathrm{mL}$, while in the intervention group was $57,87 \mathrm{pg} / \mathrm{mL}$. Both groups showed iron deficiency. Whereas WHO categorizes iron deficiency as sTfR $>21,7 \mathrm{pg} / \mathrm{mL}$.

Iron deficiency without anemia can occur when in early phase or not severe enough to decrease heamoglobin level. ${ }^{17}$ The increasing $\mathrm{Hb}$ level in our study was 3 times higher than in the previous study. Increasing $\mathrm{Hb}$ level is caused by iron supplementation promoting the amount of erytrocyte, iron deposition, functional iron level, and enhance haematopoiesis. Increasing the $\mathrm{Hb}$ level in this study was not significant, it may be due to the short duration of this study, less than erytrocyte production time 120 days. A study by Minchella et al. concludes that Hb increases in tuberculosis patients after 2 months with ATD drugs. ${ }^{18}$

Elevated IL-12 post-treatment in this study was 0.5 times higher than in the previous study on pulmonary TB. IL-12 in the control group was increasing also. In adition to the antimicrobial effect, ATD also has an imunostimulator effect. ${ }^{19}$ De Oliver et al. report post-ATD treatment in pulmonary TB receptor and expression of both limphocytes and monocytes, therefore IL-12 in the control group also increased. ${ }^{20}$ The correlation test used the Pearson method between sTfR and IL-12 with coefficient correlation $-0,73$, which means a strong correlation between decreasing sTfR level to increasing il-12. Iron supplementation increasing IL-12 is caused by activated macrophage derived monocyte and activate latent phase into active phase of IL-12. ${ }^{10}$ This is probably due to the shorter duration of this study than increasing the iron enterocyte deposition.

Decrease level of StfR post-treatment $35,61 \mathrm{pg} / \mathrm{mL}$, is lower in a previous study on pulmonary TB. This was possibly caused by the shorter duration of this study. Iron suplementation leads to a reduced receptor in the plasma membrane and increasing iron enterocyte deposition; therefore stfR is decreased..$^{10}$ ATD without iron suplementation will increase iron level due to reduce inflammation leads to decreasing siderophores and ferritin; therefore iron acquisition by MTb was decreased and iron absorption was increased.6 The averange iron level posttreatment in the control group was $36,26 \mathrm{pg} /$ $\mathrm{mL}$ and still above $21,7 \mathrm{pg} / \mathrm{mL}$; therefore iron deficiency in the control group was not been corrected.

Subagyo et al. report baseline for multiple drug resistence for pulmonary TB is sTfR> $60,26 \mathrm{pg} / \mathrm{mL}, \quad \mathrm{IL}-12<15,56 \mathrm{pg} / \mathrm{mL}$, Hb 9,5 gr\%.10 Although there was not a study baseline for spondylitis TB, this should be considered given both spondylitis TB and pulmonary TB are caused by similar microorganisme and pathology. In our control group post-treatment study were four subjects that had IL-12 level below baseline, three subjects with sTfR level above the baseline, and four subjects with $\mathrm{Hb}$ below baseline. In the control group study there were seven subjects $(41,18 \%)$ that got a risk of MDR, and one subject with a multiple risk factor. Whereas in the intervention group, only three subjects $(17,65 \%)$ got a risk factor of MDR, none of them reached the base line for sTfR and IL-12 level. From our study, it appeared that iron supplementation group had a lower risk of MDR compared to the control group.

In this study, those factors were among the uncontrollable factors. So, the samples that are not homogenous become potentially making the two groups less homogeneous, 
which is one of the limitations of this study. Other limitations of this study are the inability to control the location of participant activities and their food consumption which might affect the iron concentration, and also the lack of patients' adherence proof to the regime of consuming iron every day.

\section{Conclusion}

Supplementation of Iron Polymaltose $357 \mathrm{mg}$ increases the efficacy of ATD in spondylitis TB with iron deficiency management. Iron Polymaltose $357 \mathrm{mg}$ is an appropriate supplement in spondylitis TB with iron deficiency treatment regimen.

\section{References}

1. World Health Organization. Global tuberculosis report. Geneva; 2018.

2. Isanaka S, Aboud S, Mugusi F, Bosch RJ, Willett WC, Spiegelman D, et al. Iron status predicts treatment failure and mortality in tuberculosis patients: a prospective cohort study from Dar es Salaam, Tanzania. PloS one. 2012;7(5):e37350.

3. Millet J MA, Fina L, Bano L, Et all. Factors that inluence current tuberculosis epidemiology. Euro Spine J. 2013;22:53948.

4. Pellise F. Tuberculosis and Pott's disease, still very relevant health problems. European spine journal: official publication of the European Spine Society, the European Spinal Deformity Society, and the European Section of the Cervical Spine Research Society. 2013;22(Suppl 4):527-8.

5. Tuli M. Historical aspects of pott,s disease (spinal tuberculosis) management. Euro J Spine. 2013;22:529-38.

6. Minchella PA, Donkor S, Owolabi O, Sutherland JS, McDermid JM. Complex anemia in tuberculosis: the need to consider causes and timing when designing interventions. Clin Infect Dis. 2015;60(5):764-72.
7. Mishra S, Taparia P, Yadav D, Koolwal S Study of iron metabolism in pulmonary tuberculosis patients. International J Health Sci Res. 2018;8(3):70-7.

8. Ganz T. Iron in innate immunity: starve and invaders. Curr Opin Immunol. 2009;21(1): 63-7.

9. Kuvibidila SR, Gardner R, Velez M, Yu L. Iron deficiency, but not underfeeding reduces the secretion of interferon-gamma by mitogen-activated murine spleen cells. Cytokine. 2010;52(3):230-7.

10. Subagyo DTL, Soeharyo H, Hadiarto M. Pengaruh suplementasi besi pada tuberkulosis (kajian respon kesembuhan, respon imun, dan resistensi). Sains Medika, J Med Health. 2010;2(1):57-69.

11. Tatar D, Senol G, Alptekin S, Gunes E, Aydin $\mathrm{M}$, Gunes O. Assessment of extrapulmonary tuberculosis in two provinces of Turkey. Iran J Public Health. 2016;45(3):305-13.

12. Moon MS. Tuberculosis of spine: current views in diagnosis and management. Asian Spine J. 2014;8(1):97-111.

13. Rajasekaran S, Khandelwal G. Drug therapy in spinal tuberculosis. European spine journal: official publication of the European Spine Society, the European Spinal Deformity Society, and the European Section of the Cervical Spine Research Society. 2013;22 (Suppl 4):587-93.

14. Cao G, Rao J, Cai Y, Wang C, Liao W, Chen T, et al. Analysis of treatment and prognosis of 863 patients with spinal tuberculosis in Guizhou Province. Biomed Res Int. 2018;2018:3265735.

15. Wang B, Kong L, Zhu Z, Gao W, Guo H, Wang $X$, et al. Recurrent complex spinal tuberculosis accompanied by sinus tract formation: causes of recurrence and clinical treatments. Sci Rep. 2018;8(1):6933.

16. Froissart A, Rossi B, Ranque B, Jarrin I, Bergmann JF, Beaune S, et al. Effect of a red blood cell transfusion on biological markers used to determine the cause of anemia: a prospective study. Am J Med. 2018;131(3):319-22.

17. Okam MM, Koch TA, Tran MH. Iron supplementation, response in iron- 
deficiency anemia: analysis of five trials. Am J Med, 2017;130(8):991.e1-8.

18. Minchella PA, Donkor S, Owolabi O, Sutherland JS, McDermid JM. Complex anemia in tuberculosis: the need to consider causes and timing when designing interventions. Clin Infect Dis. 2015;60(5):764-72

19. Mendez S, Traslavina R, Hinchman $M$, Huang L, Green P, Cynamon MH, et al. The antituberculosis drug pyrazinamide affects the course of cutaneous leishmaniasis in vivo and increases activation of macrophages and dendritic cells. Antimicrob Agents Chemother. 2009;53(12):5114-21.

20. de Oliveira LR, Peresi E, Golim Mde A, Gatto M, Araujo Junior JP, da Costa EA, et al. Analysis of Toll-like receptors, iNOS and cytokine profiles in patients with pulmonary tuberculosis during anti-tuberculosis treatment. PloS one. 2014;9(2):e88572. 